Revista lus et Praxis, Año 23, № 2, 2017, pp. 21 - 50

ISSN 0717 - 2877

Universidad de Talca - Facultad de Ciencias Jurídicas y Sociales

La problemática de los juicios paralelos en la jurisprudencia y doctrina española

Francisco J. Leturia I.

Trabajo recibido el 1 de diciembre de 2015 y aprobado el 15 de mayo de 2016

\title{
La problemática de los juicios paralelos \\ en la jurisprudencia y doctrina española
}

The problem of parallel trials IN THE Spanish

JURISPRUDENCE AND DOCTRINE

Francisco J. Leturia I.*

\section{RESUMEN}

Uno de los asuntos que más ha llamado la atención de la opinión pública durante las últimas décadas es la creciente tensión que existe entre los tribunales de justicia y los medios de comunicación. Se ha acuñado la expresión "justicia paralela" o "justicia mediática" para referirse a todas aquellas actuaciones realizadas al margen del proceso jurisdiccional, y que en alguna medida se superponen a la misma, investigando, aportando pruebas y realizando juicios de inocencia o culpabilidad que no siempre coinciden, generando una situación compleja y que puede afectar a una serie de derechos. Ello deja en evidencia una amplia área sin regulación adecuada, donde entran en conflicto las principales libertades expresivas con la necesidad de protección del proceso y de los derechos de las partes y donde no hay claridad de cómo proceder. La materia presentada es de interés global, y la doctrina y la jurisprudencia española ha hecho valiosos aportes y reflexiones en este sentido, señalando que al mismo tiempo que la importancia y necesidad de una amplia publicidad mediática sobre los asuntos de interés público -y tanto los hechos delictuales como los juicios lo son-, es necesario avanzar en la protección del proceso y de las personas muchas veces injusta o inadecuadamente aludidas.

ABSTRACT

One of the issues that has caught the attention of public opinion over the last decades is the growing tension between the courts and the media. The term "parallel trials" or "media justice" has been coined to refer to all actions undertaken outside the judicial process, and which to some extent overlap then in; researching, generating evidence and making judgments of innocence or guilt The two do not always coincide, creating a complex situation that can affect a number of rights. This reveals a wide area lacking adequate regulation, where freedom of expresion comes into conflict with the need to protect due process and the rights of the parties, and where there is no clarity on how to proceed. The material presented is of global concern, and one in which Spanish doctrine and jurisprudence has made valuable contributions and provided insights in this regard, by noting that while the importance and necessity of extensive media atention to matters of public interest -and both criminal and tort judgments are- it is

\footnotetext{
* Abogado. Licenciado en Derecho, Pontificia Universidad Católica de Chile. Doctor, Universidad de Salamanca (España). Profesor Departamento de Derecho Público y Departamento de Derecho Procesal, Pontificia Universidad Católica de Chile. Presidente del Centro Nacional de Arbitrajes. Correo electrónico: fjleturia@uc.cl.
} 
necessary to advance in the protection of due process and of individuals who can often be unfairly or improperly alluded to.

Palabras Clave

Justicia paralela, Justicia mediática, Debido proceso

KEY WORDS

Parallel trials, Media justice, Due process

\section{Introducción}

Sobre el proceso judicial y sobre los hechos que en ellos se tratan confluyen dos derechos fundamentales: la libertad de expresión y el principio de la publicidad de las actuaciones procesales.

Esta doble protección limita con especial fuerza la posibilidad de restringir la difusión de las informaciones sobre asuntos judiciales. No obstante, hay consenso general sobre la necesidad de abordar una serie de problemas y tensiones vinculados precisamente a su difusión pública, y que pueden afectar gravemente tanto al proceso mismo, como a los derechos de quienes intervienen en él.

En las páginas siguientes analizaremos, desde una perspectiva jurídica, la problemática de los Ilamados "juicios paralelos". La expresión ha sido ampliamente utilizada tanto en el lenguaje periodístico como legal, dando cuenta de uno de los problemas jurídicos globales más complejos e interesantes de la actualidad'.

En el fondo de nuestro análisis subyace como problema central el hecho de que el trabajo realizado por la prensa en relación con hechos delictuales coincidirá en muchos aspectos con el realizado por los Tribunales de Justicia. En efecto, ambos investigan, informan, emiten juicios y opiniones sobre la prueba y la participación de los involucrados; se pronuncian sobre la imparcialidad de los jueces, la neutralidad de testigos y peritos, entre otras.

Los efectos sociales de esta exposición mediática muchas veces serán observados como una suerte de pena anticipada o extralegal, completamente independiente del resultado del juicio y de las garantías universales establecidas para nuestra protección.

\footnotetext{
1 Cortés (2003), p. 126. La problemática no es nueva, pero el desarrollo de la prensa y la tecnología, junto con el creciente interés noticioso en los asuntos judiciales, ha levantado el tema. De hecho, una Circular del 2 de enero de 1899 del entonces Fiscal Jefe del Tribunal Supremo señala: "Existe una determinada prensa interesada en instruir un segundo sumario, ya con datos que la infidelidad de algún funcionario proporciona, ya con rumores recogidos donde la suerte les repara si las noticias son verdaderas, se burlan las previsiones y desvelos de la justicia, y si son falsas se extravía a la opinión el menoscabo de la moral y el posible prestigio de los tribunales".
} 
Las diferentes técnicas, propósitos, criterios, tiempos, y sobre todo, exigencias y limitaciones legales que enfrentan ambos, darán pie a una serie de situaciones problemáticas y que a la opinión pública le resulta complejo asimilar.

Ni la doctrina ni los sistemas normativos de ningún país han logrado, hasta ahora, resolver esta situación en forma satisfactoria ${ }^{2}$, aunque existe consenso en que se trata de una patología jurídica de especial gravedad y que puede llegar a afectar las bases mismas del estado de derecho ${ }^{3}$.

\section{Existencia de diversos conceptos de "juicio paralelo"}

Si bien el uso de la expresión "justicia paralela" o "justicia mediática" es ya común, y aunque su propio nombre hace referencia a una situación evidente, no existe consenso sobre su contenido exacto, utilizándosela a menudo para abarcar una variada gama de situaciones consideradas inadecuadas, generando confusiones y equívocos que dificultan su tratamiento, y que convendrá aclarar antes de profundizar en su estudio ${ }^{4}$.

Para intentar delimitar su significado, diremos, como primera aproximación, que el concepto de "juicio paralelo" podría vincularse al seguimiento publicitado de un hecho aparentemente delictivo, realizado por la prensa al margen del cauce institucional.

Esta primera definición no describe necesariamente una actividad negativa, pues podría corresponder a un correcto ejercicio de la actividad periodística, realizado bajo el amparo de la libertad de información, sobre asuntos de interés público (los procesos judiciales ${ }^{5}$ ), que son además cubiertos por la exigencia de la publicidad procesal ${ }^{6}$. Bajo esta comprensión podría sostenerse que los

\footnotetext{
2 Roxin (1999), p. 74.

${ }^{3}$ Gimeno (1998), p. 305.

${ }^{4}$ Más allá de las diferentes concepciones relativas a lo que cabe dentro de esta expresión, puede encontrarse un interesante listado de casos recientes en el trabajo de FERNÁNDEZ (2012), pp. 1-16.
}

${ }^{5}$ STC 178/1993, FJ 8: "Esta exigencia ha sido reiteradamente establecida por la doctrina de este Tribunal, que ha estimado la existencia de acontecimientos noticiables en los sucesos de relevancia penal (STC 178/1993; y STC 320/1994), y ello con independencia del carácter de sujeto privado de la persona afectada por la noticia (STC 320/1994), apreciándose, asimismo, que la relevancia pública de los hechos ha de ser también reconocida respecto de los que hayan alcanzado notoriedad (STC 3/1997)". También STC 154/1999, FJ 4, haciendo referencia a STC 178/1993; a STC 320/1994 y a STC 320/1994. En un sentido similar, STC 30/1982; STC 23/1985. También CEDH № 23118/93, Nilsen and Johnsen v. Noruega, de 25 de noviembre de 1999, párrafo 46; CEDH No 17419/90, Wingrove v. Reino Unido, de 25 de noviembre de 1996, párrafo 58; y CEDH № 26682/95, Sürek v. Turquía (Nº 1), de 8 de julio de 1999, párrafo 61.

${ }^{6}$ ATC 195/1991, FJ 6. 
juicios paralelos son algo consustancial a las sociedades democráticas ${ }^{7}$ y que configuran una situación valiosa, deseable e importante, pues la amplia investigación y difusión de asuntos judiciales es unánimemente reconocida como un asunto sobre el que conviene contar con la mayor y más variada cobertura informativa ${ }^{8}$.

Pero en la doctrina y la jurisprudencia mayoritaria, la expresión "juicio paralelo" tiene una connotación negativa y se vincula con la afectación injustificada de numerosos derechos y bienes jurídicos fuertemente protegidos ${ }^{9}$, tales como la presunción de inocencia, el honor, la intimidad, la privacidad, la independencia e imparcialidad del juzgador, la credibilidad y el prestigio de los tribunales, entre otros, realizado al amparo, supuestamente, de las garantías constitucionales de libertad de expresión e información y del principio de publicidad procesal.

Por ello, una definición más completa y relevante desde un punto de vista jurídico debe hacer referencia a la capacidad que el tratamiento informativo de ciertos hechos podría tener frente a diversos bienes protegidos y vinculados a un proceso judicial ${ }^{10}$.

En esta línea, Bravo define el juicio paralelo como "aquel conjunto de informaciones sobre un asunto sub iudice, con las que los medios de comunicación pretenden examinar y valorar el proceso, las pruebas practicadas y a las personas implicadas en los hechos sometidos a investigación. Así definido, supera la dicotomía justicia-prensa para convertirse en un conflicto entre la libertad de opinar e informar acerca de los procesos judiciales en curso y los derechos del acusado a un proceso justo. Los medios asumen el papel de juez e inducen a un veredicto anticipado de culpabilidad a la opinión pública, lo que vulnera la presunción de inocencia del encausado y, por tanto, menoscaba su derecho al honor"11.

Espín Templado, por su parte, define el juicio paralelo como el "conjunto de informaciones aparecidas a lo largo de un periodo de tiempo en los medios

\footnotetext{
7 JUANES (2012), pp. 103-104.
}

${ }^{8}$ Podría hablarse de juicios paralelos informativos, generalmente sin mayor relevancia jurídica, y los juicios paralelos capaces de lesionar los bienes jurídicos protegidos constitucionalmente. Para Juanes, los primeros ni siquiera constituirían una situación de un "juicio paralelo". JUANES (2007), p. 63.

${ }^{9}$ Declaración del Pleno del CGPJ, de 25 de enero de 1995.

10 Por todo ello, Orenes Ruiz se refiere al "proceso paralelo" como "el paradigma del inadecuado ejercicio de las libertades informativas sobre un proceso judicial", resaltando su capacidad para "atentar de forma simultánea contra diversos derechos fundamentales y otros bienes jurídicos dignos de protección, y que, en último término, afecta al derecho a un proceso justo e imparcial". Orenes (2008), p. 265.

11 Bravo (2012), p. 48. 
de comunicación, sobre un asunto sub iudice, a través de los cuales se efectúa una valoración sobre la regularidad legal y ética del comportamiento de personas implicadas en los hechos sometidos a dicha investigación judicial"12.

Latorre Latorre se refiere a los juicios paralelos como "todo proceso generado e instrumentado en y por los medios de comunicación, erigiéndose en jueces sobre un asunto sub iudice y anticipando la culpabilidad del imputado, o desacreditando el proceso con el fin de influir en la decisión del tribunal trocando su imparcialidad, de modo que cualquier lector/televidente tendría la impresión de que la jurisdicción penal no tendría otro recurso que sentenciar en los términos implicados". Pero agrega que lo relevante no es lo sub iudice (aunque por cierto el impacto es mayor cuando el asunto no se encuentra concluido), sino el potencial de crear, por el solo mérito de la información periodística, una opinión pública específica sobre un asunto que debe ser o ha sido resuelto en los tribunales ${ }^{13}$.

Para Juanes Peces, los juicios paralelos pueden ocurrir antes y durante los procesos judiciales y pueden tomar incluso la forma de "campañas sistemáticas a favor o en contra de las personas enjuiciadas... Tal valoración se convierte ante la opinión pública en una suerte de proceso en el que los medios de comunicación ejercen los papeles de fiscal y abogado defensor... creando en la opinión pública un estado de opinión concreto... sin esperar al resultado del juicio"14.

Rodríguez Fernández los define como "la calificación o juicio que personas, colectivos o la propia sociedad formula sobre un determinado asunto o persona al margen del proceso, siendo generalmente los medios de comunicación quienes juzgan asuntos al inicio y durante la instrucción, así como durante la celebración del juicio oral, del plenario del proceso judicial"15. Luego señala que "para que exista un juicio paralelo se requiere un proceso judicial en marcha, que se anticipe la culpabilidad o la inocencia del procesado a través de los medios de comunicación y que lo que se pretenda sea perturbar o alterar la imparcialidad del Tribunal, de modo que cualquier lector, oyente o espectador se queda con la impresión de que la jurisdicción tiene que sentenciar en los términos en los que se expresan los medios de comunicación"16.

\footnotetext{
12 Espín (1990), p. 123.

13 Latorre (2002), p. 105.

14 Revista del Poder Judicial (1999).

15 RodríGuez (2012), p. 2.

${ }^{16}$ RodríGuez (2012), p. 2.
} 
Prat señala que "el juicio paralelo se identifica por unos presupuestos: dar a conocer unos hechos empleando a testigos, peritos, documentos, cintas de vídeo o magnetofónicas, o cualquier otro medio con virtualidad probatoria y que éstos son presentados por personas ajenas al proceso judicial o intervinientes en el mismo. Como consecuencia de estos presupuestos se concluye en la producción de unos efectos en el ciudadano perceptor de la noticia y en el órgano jurisdiccional. Los efectos son: la desconfianza en la Administración de Justicia, un peligro de que la resolución pueda ser injusta, entendiendo por injusta la ausencia de condiciones de imparcialidad, dictada por aquellos a quienes corresponde juzgar y ejecutar lo juzgado o, bien, aunque la resolución sea justa, es posible que debido al juicio paralelo parte de la sociedad la vea y considere injusta"17.

Para Orenes Ruiz, lo que caracteriza a un auténtico juicio paralelo "es su capacidad para trasladar al público una determinada versión de los hechos, para crear, en la opinión pública, un estado de opinión a favor o en contra de los actores del proceso: su aptitud directa o indirecta, ya sea buscada de forma intencionada o no, de dar, traslucir, anticipar o sugerir, en definitiva, de hacer llegar al ciudadano un veredicto de inocencia o de culpabilidad antes de la celebración del juicio"18.

En el mundo judicial tampoco existe consenso sobre lo que es un juicio paralelo. Por ejemplo, los magistrados encuestados en el "I Encuentro de Jueces-Periodistas" señalaron que había juicio paralelo en la entrega de datos sesgados, opiniones que pretenden decantar la opinión pública, prejuzgando la cuestión, resolviendo el caso al margen del proceso comprometiendo la confianza de los tribunales, asistiendo a los medios informativos personas intervinientes en el proceso, anticipando valoraciones que pueden corresponder a los Tribunales, entrevistas y opiniones fuera del proceso, conformando un veredicto extraprocesal ${ }^{19}$. Por otro lado, aunque tanto el TS como el TC se refieren al término, no lo hacen con la misma extensión. Ambos destacan su impacto sobre la imparcialidad y reputación de los Tribunales, pero sólo el Tribunal Supremo considera expresamente su capacidad para afectar también al honor y a la presunción de inocencia ${ }^{20}$.

17 PRAT (2001), p. 5.

18 Orenes (2008), p. 267.

19 Revista del Poder Judicial (1999), pregunta 13.

20 STS de 9 de febrero de 2004, que señaló que "el referido reportaje, al contener juicios de valor sobre la culpabilidad del actor, no ya en forma precisamente subliminal, sino bien clara y patente, a modo de juicio paralelo, a los que tan aficionada es la prensa, y que más que informar desinforman y atacan frontalmente el principio constitucional de presunción de inocencia, predisponiendo a la 


\section{Delimitación del concepto de "juicio paralelo"}

Para efectos de este trabajo, partiremos de la base de que la existencia de un juicio paralelo requiere la existencia de un proceso judicial entendido en un sentido amplio. Es decir, abarcará la etapa judicial propiamente tal, la de sumario, e incluso el tiempo que transcurre entre la comisión del delito y el inicio de cualquier investigación oficial ${ }^{21}$.

La crítica al Poder Judicial o las agresiones mediáticas de cualquier tipo son también situaciones complejas que pueden afectar gravemente el desarrollo del proceso y/o los derechos de las partes y demás intervinientes en un juicio y requieren un análisis y tratamiento jurídico especial, parcialmente distinto y coincidente con el acá desarrollado. Lo mismo ocurre con la publicidad que afecte a sentencias firmes y a procesos ya terminados ${ }^{22}$. Pero estas situaciones no serán abordadas en este trabajo, al menos en forma directa.

Por todo lo ya dicho, parece claro que desde un punto de vista práctico, orientado a la búsqueda de soluciones y propuestas, sería más útil analizar esta temática según la capacidad efectiva que tengan ciertas acciones o conjuntos de acciones para afectar significativamente bienes jurídicos relevantes. El ejercicio de clasificar una expresión dentro o fuera de la definición de "juicio paralelo" no ofrece gran ayuda ${ }^{23}$, aunque seguiremos utilizando la expresión a lo largo de este trabajo, dado lo ampliamente difundida de la misma.

opinión pública contra la persona que se señala, la que indudablemente resulta así desprestigiada y vejada, por someterla así a un ataque injustificado a su honor, dignidad y estima propia y por los demás, como aquí sucede... divulgación irresponsable por tendenciosa y marcada a protagonizar al demandante como autor comprobado del delito de agresión sexual, del que fue absuelto por sentencia". El Tribunal Supremo también ha reconocido la capacidad de que el desarrollo de un juicio con todas las garantías y el derecho a la presunción de inocencia pueden ser afectados por "el clima social imperante". STS de 4 de marzo de 1991.

${ }^{21}$ En el mismo sentido, Rodrícuez (2012), pp. 2 y ss.

22 En este caso, más que un "juicio paralelo", tendremos una acción comunicativa que afecta un derecho constitucionalmente protegido y será posible regularlo en consecuencia. Ver, sobre el particular, el desarrollo dado al Ilamado "derecho al olvido" en Palermo (2010), y Mezzanotte (2009). La jurisprudencia comparada conoce numerosos casos donde se ha restringido la difusión mediática de condenas o confesiones anteriores, mientras se desarrollan otros juicios de gran sensibilidad mediática. Nebraska Press Assn. v. Stuart, 427 U.S. 539 (1976).

${ }^{23}$ Pese a que toda la lógica de la jurisprudencia construida sobre esta materia se refiere a las declaraciones realizadas mientras está pendiente la solución de un asunto judicial, el Tribunal Constitucional, en la veintena de resoluciones donde trata el asunto, se refiere indistintamente a la protección frente a "declaraciones en los medios de comunicación acerca de procesos en curso y frente a juicios paralelos". Estimamos que con ello se ha querido utilizar una expresión más comprensiva de las situaciones de riesgo que conviene limitar, pues bien podría darse el caso de expresiones aisladas (que no formaran parte de un juicio paralelo) o de situaciones que por los criterios utilizados para 
Jurídicamente, las comunicaciones relevantes serán aquellas que puedan afectar o entrar en conflicto con otros derechos protegidos. Por ello, no repararemos en las informaciones sobre un juicio pendiente si ellas no tienen la capacidad para afectar la imparcialidad judicial e influir razonablemente en su resultado, ni aun cuando ellas realicen conjeturas sobre el mismo y la participación que quepa a diversas personas ${ }^{24}$.

Por otro lado, antes de continuar con nuestro análisis, creemos importante señalar que en materias de comunicación el efecto no siempre será producto de la voluntad del "emisor", sino que dependerá en buena medida del receptor y de un conjunto de factores ambientales, lo que muchas veces hace inadecuado e insuficiente buscar responsabilidades individuales (dolosas), cuando el objetivo es garantizar un determinado estado de cosas fundamentales (el debido proceso, etc. $)^{25}$, lo que hace que el tratamiento normativo de estas informaciones sea mucho más complejo.

\section{Principales bienes jurídicos afectados por los juicios paralelos}

Los bienes jurídicos afectados por las comunicaciones relativas a procesos judiciales pendientes son múltiples y ninguna lista podría agotarlos. Es claro que entre ellos estarán el derecho a un proceso debido y a un juicio justo, el derecho al honor, a la propia imagen, a la intimidad personal y familiar, y la presunción de inocencia ${ }^{26}$. Sin embargo, nos referiremos a los que nos han parecido principales, y más concretamente, a los relacionados con el derecho a un juicio justo: imparcialidad y presunción de inocencia, considerando dentro de esta última el derecho a no ser condenado y sancionado mediáticamente.

\section{a) Imparcialidad judicial}

La forma en que las acciones informativas pueden afectar la imparcialidad del juzgador es múltiple. Y pueden alcanzar tanto la imparcialidad material u objetiva del juez, como la confianza colectiva que debe existir sobre él en cuanto a su capacidad para comportarse de acuerdo a las exigencias de su rol (imparcialidad subjetiva) ${ }^{27}$.

definir a un juicio mediático (intensidad, etc.) pudieran escapar del ámbito que esta jurisprudencia ha querido abarcar.

${ }^{24}$ JUANES (2007), p. 63. En un sentido similar, ATC 195/1991, FJ 6; STC 136/1999, FJ 9.

${ }^{25}$ Roxin (1999), pp. 79 y 81.

${ }^{26}$ RodríGuez (2012), pp. 1 y 2.

27 STC 162/1999, FJ 5; STC 151/2000, FJ 3; STC 69/2001, FJ 6, y STC 155/2002. Bujosa destaca la importancia de la apariencia de imparcialidad de cara a los justiciables y a todo el cuerpo social. BuJOSA (2007), p. 56. 
Tanto el TCE como el TS han sido categóricos al señalar que las expectativas generadas en la opinión pública mediante informaciones relativas a un caso pendiente "pueden Ilegar a menoscabar, según sea su tenor, finalidad y contexto, la imparcialidad o la apariencia de imparcialidad de los Jueces y Tribunales", reconociendo que lo publicado puede influir en la decisión de los jueces, así como hacerles llegar informaciones que no están en el proceso y que no han gozado de la protección y garantías del proceso ${ }^{28}$.

EI TCE ha señalado que cuando ello ocurre, se conculca el derecho a un proceso con todas las garantías, y "dada la naturaleza de los valores implicados", ni siquiera sería necesario probar que "la influencia ejercida ha tenido un efecto concreto en la decisión de la causa", bastando "la probabilidad fundada de que tal influencia ha tenido lugar" ${ }^{\prime \prime 2}$.

La información sobre hechos del pasado puede afectar, en algunos casos, la imparcialidad del juzgador, tal como ha sido señalado por los estudiosos del derecho al olvido ${ }^{30}$.

\section{b) Presunción de inocencia y anticipación o exacerbación de la condena}

La presunción de inocencia puede ser entendida como un derecho procesal oponible a todos los órganos del Estado ${ }^{31}$ y como un principio jurídico general, cuyo respeto y aplicación se desea también entre los actores privados, pero que no resulta exigible con la misma intensidad con que lo es en su vertiente de garantía procesal fundamental ${ }^{32}$.

28 STC 136/1999, referido al caso de la Mesa Nacional de HB, señalaba en su FJ 8 que la salvaguarda de la "autoridad e imparcialidad" del Poder Judicial puede exigir restricciones a la libertad de expresión e información. Sólo una doctrina muy minoritaria niega la capacidad de los juicios paralelos para afectar el proceso, "salvo que la jurisdicción esté a cargo de personas inadecuadas para ejercerla". QUINTERO (1990), p. 358.

29 STC 136/1999, FJ 8, citando la sentencia CEDH № 22714/93, Worm v. Austria, de 29 de agosto de 1997, párrafo 54 (por ambas citas). El destacado de la primera cita es nuestro.

30 JUANES (2012), pp. 108-109. La publicidad masiva dada a una sentencia ya cumplida, por ejemplo, junto con estigmatizar al delincuente rehabilitado, puede afectar la imparcialidad de un juez o un jurado de un caso nuevo. Ver también cita 22 de este trabajo.

31 Pese a ser una garantía de origen procesal, obliga, además de los jueces, a todos los órganos y funcionarios públicos. Ver, por todas, CEDH No 15175/89, Allenet de Ribemont v. Francia, de 10 de febrero de 1995. En el mismo sentido, se ha pronunciado la Corte Interamericana de Derechos Humanos. CIDH, Lori Berenson v. Perú, sentencia de 24 de noviembre de 2004, párrafo 159.

32 STC 166/1995, FJ 3, ha señalado "el derecho a recibir la consideración y el trato de no autor y no partícipe en hechos de carácter delictivo o análogos a estos y determina por ende el derecho a que no se apliquen las consecuencias o los efectos jurídicos anudados a hechos de tal naturaleza en las relaciones jurídicas de todo tipo" (cursiva es nuestra). Este criterio ya se encuentra en la STC 109/1986, FJ 1 y 2, y en STC 128/1995, FJ 3, y en la ya citada STS de 9 de febrero de 2004, pese a que en Espa- 
Ello nos enfrenta a un escenario complejo, pues las opiniones y antecedentes difundidos en ejercicio de la libertad de información, expresión y opinión podrían afectar tanto a la imparcialidad del juzgador, a la actitud de otros intervinientes en el juicio (testigos, peritos, etc.) o a las personas aludidas (aunque ello generalmente corresponderá más bien a un daño a su honra u otros derechos).

Por ello, tanto el TCE como la CEDH han señalado que pueden establecerse restricciones a la libertad de expresión cuando se afecte la presunción de inocencia, entendida en un sentido amplio, es decir, cuando lo informado puede llevar "a la conclusión de que los acusados son culpables, prediciendo la condena" 33 .

La CEDH ha profundizado en el tema, agregando que "las autoridades y sobre todo aquellas que tienen a su cargo las investigaciones y los procesos penales deben mostrarse muy prudentes a la hora de hacer declaraciones públicas sobre los asuntos o personas objeto de investigación judicial, a fin de evitar en lo posible, que estas declaraciones sean mal interpretadas por el público y conduzcan a poner en cuestión la inocencia del acusado" ${ }^{34}$, resaltando la amplitud con que debe ser entendido este criterio. El Libro Verde sobre la presunción de inocencia, por su parte, haciendo referencia al mismo principio, señala que "las autoridades pueden informar públicamente de las investigaciones y expresar sospechas de culpabilidad, siempre que la sospecha no sea una declaración de culpabilidad del acusado, y se manifieste con discreción y prudencia" ${ }^{\prime 3}$.

ña no encuentra una norma legal que la consagre expresamente. A nivel doctrinario, PuLIDO (2008), pp. 9-12; UNIÓN EUROPEA (2006), 174 final.

33 STC 136/1999.

${ }^{34}$ CEDH No 15175/89, Allenet de Ribemont v. Francia, de 10 de febrero de 1995, párrafo 36-46. En este se aborda las declaraciones públicas que señalaban a una persona como instigadora de un asesinato. La CEDH consideró que fueron los medios y no las autoridades los que afectaron la presunción de inocencia, y esta solo tiene eficacia frente a los funcionarios públicos (párrafo 46).

35 UnIÓN EUROPEA (2006), 174 final, Título 2.1, referida a la declaración de culpabilidad con anterioridad al juicio. El Tribunal Constitucional, por su parte, se refirió a estos criterios en su STC 244/2007. El caso se refiere a la información suministrada por el Gobernador civil en rueda de prensa, dando cuenta de una operación antiterrorista y la detención de varias personas, a quienes individualizó y vinculó con diversos crímenes, uno de los cuales (el reclamante de amparo) fue puesto en libertad sin cargos días más tarde, siendo archivadas las diligencias respecto a su persona. Juanes se pronuncia en el mismo sentido, señalando que así lo han entendido tanto la Comisión Europea de Derechos Humanos (en el caso Petra Krause (Suiza), reiterada después en el caso $X$ contra (Austria, R.F. y S.F.) y finalmente en el caso M. Berns y J. Ewert contra Luxemburgo), como el Tribunal Europeo de Derechos Humanos (caso Allenet de Ribemont, de 10 de febrero de 1995). JuANEs (2007), p. 63; JuANES (1999), p. 31; Titium (1999). 
EI TC ha exigido a la prensa un mayor grado de diligencia y cuidado para acceder a la protección constitucional de la libertad de información, cuando pueda resultar afectada la presunción de inocencia de un imputado, entendida esta en un sentido amplio ${ }^{36}$. Además, ha señalado que esta diligencia se extiende a la forma utilizada para comunicar la información ${ }^{37}$.

Con el mismo propósito de aumentar el respeto general sobre la presunción de inocencia, se han establecido algunas medidas adicionales, como por ejemplo el deber de reserva que afecta a los jueces y que los limita significativamente en su ejercicio de la libertad de expresión ${ }^{38}$, o el propio secreto de sumario ${ }^{39}$. La CEDH ha señalado que incluso los periodistas están obligados a respetar ciertos límites en el ejercicio de su profesión, entre los que se encuentra en un lugar destacado la presunción de inocencia en las narraciones que hicieran sobre procesos penales ${ }^{40}$.

Otra cuestión de interés, directamente vinculada a la presunción de inocencia, es la capacidad de la prensa de anticipar juicios de inocencia o culpabilidad, generando presiones y complejas situaciones en caso de que las expectativas generadas luego sean frustradas por la decisión judicial.

Es claro que los Tribunales de Justicia ostentan el monopolio para aplicar sanciones legales, autorías y culpabilidades, por lo que no puede hablarse de

36 STC 219/1992, FJ 5; STC 28/1996, FJ 3; STC 54/2004, FJ 3; STC 1/2005, FJ 5.

37 STC 219/1992, FJ 1; y STC 54/2004, FJ 2. El TS ha señalado que las inexactitudes que en general se aceptan en la comunicación de determinados hechos tienen un espacio menor cuando pueden afectar la presunción de inocencia. STS de 3 de diciembre de 1992: "No es admisible por tanto no puede conocer la diferencia entre el autor de un delito o el presunto autor (...) de manera que ningún profesional del periodismo puede excusar su ignorancia (...)".

38 STC 162/1999, FJ 9.

${ }^{39}$ Carnelutti (1961), p. 125. La instrucción 3/1993 de la Fiscalía General del Estado ve en el secreto de sumario una herramienta para proteger "al menos en parte" el honor de los procesados hasta la condena, haciendo extensivo el efecto extraprocesal de la presunción de inocencia.

${ }^{40}$ CEDH No 34000/96, Roy et Malaurie v. Francia, de 3 de octubre de 2000, párrafo 34. Ya en el caso CEDH No 22714/93, Worm v. Austria, de 29 de agosto de 1997, el Gobierno justificaba la restricción a la libertad de expresión en la presunción de inocencia (párrafos 41 y 42), aunque en ese caso el Tribunal resolvió el caso considerando innecesario referirse a este punto. Una doctrina similar se aprecia en el CEDH No 28070/06, A. v. Noruega, de 9 de abril de 2009, párrafo 55. Estos criterios pueden verse aplicados en el caso que afectó al marido de una mujer desaparecida, cuando sus cuñadas acudieron a un canal de televisión inculpándolo, cuando el caso se encontraba ya sobreseído. Frente a estos hechos, el Tribunal Constitucional rechazó las alegaciones de interés público y reportaje neutral, señalando, por el contrario, que "las manifestaciones realizadas no se limitaron a narrar hechos de veracidad comprobada, sino que presentaron ante la opinión pública a la persona objeto de dichas informaciones como autor real y verdadero de un asesinato, hasta el punto de calificarlo literalmente de 'asesino'", por lo que se consideró que el nivel de diligencia utilizado fue inferior al requerido. STC 139/1997, Parte I. 2. a), c) y FJ 9 y 10. 
"penas mediáticas". Sin embargo, los derechos afectados por esta vía pueden irrogar perjuicios que desde un punto de vista subjetivo serán más relevantes para quien los sufre que las penas establecidas por ley, generando una situación que amerita una cuidadosa atención y tratamiento ${ }^{41}$.

Especialmente, porque las amplias garantías constitucionales otorgadas a los informadores pueden generar un espacio con incentivos para la utilización de la prensa como un mecanismo de justicia alternativa, paralela, no sujeta a garantías y, para colmo, más controlable (para algunos). El propio TC ha hablado de una cierta usurpación de funciones cuando "se incita al público a formarse una opinión sobre el objeto de una causa pendiente de Sentencia, o si las partes sufrieran un pseudo juicio en los medios de comunicación" ${ }^{42}$.

Cabe preguntarse si las sentencias judiciales, teniendo el requisito constitucional de ser públicas, tienen o pueden tener como propósito el de generar en la opinión pública un efecto determinado, con un móvil de prevención general o simplemente de reafirmar la confianza en la autoridad de los tribunales y en la vigencia del imperio del derecho.

Si en la misma línea se sostuviera que el juicio de reproche colectivo, consecuencia natural y previsible del principio de publicidad extendido sobre la sentencia condenatoria, es parte de la sanción penal o del sistema punitivo que las establece, enfrentaremos un problema más complejo, vinculado a una pena no estricta, no cuantificable ni controlable. A ello se suma que los maltratos mediáticos normalmente no pueden ser reparados tras la absolución, lo que debiera constituir un Ilamado de atención para quienes se enfrenten a esta cuestión ${ }^{43}$.

\footnotetext{
${ }^{41}$ La libertad editorial y de opinión permitirán anticipar conclusiones y referirse a los involucrados con amplia libertad. Pero debe tenerse presente que las manipulaciones que realice la prensa son especialmente graves porque, en la práctica, los auditores y lectores generalmente confían en los medios que siguen y para muchos ellos constituirán la única fuente de información. Ver sobre este tema CARRILLO (2004).

42 ATC 195/1991 se refiere directamente a las lesiones que pueden provocar a la actividad jurisdiccional las actuaciones realizadas por la prensa, aunque reconoce el carácter público y noticioso de los procedimientos penales, en especial luego de la apertura del juicio oral. En el mismo sentido, STC 69/2001, FJ 6; STEDH Sunday Times, 26 de abril de 1979, FJ 63; STEDH del caso Worm, de 29 de agosto de 1997, párrafo 54.

${ }^{43}$ Rodríguez Ramos utiliza la expresión "maltrato mediático" y señala que los medios tienen cierta impunidad y se permiten maltratar por "la generosa interpretación del derecho deber de información en esta materia" y por el temor reverencial de todos los poderes, incluyendo el judicial, a resultar "estigmatizados por los medios de comunicación". Rodrícuez (2002), pp. 1-3. Quienes no cuentan con los conocimientos jurídicos y procesales adecuados pueden considerar culpable a una persona por el solo hecho de verse involucrada en un proceso penal, con las consecuentes situaciones de descrédito y sufrimiento de diverso tipo que ello provoca. De VEGA (1998), p. 68. Ver también en este sentido, Roxin (1999), pp. 73-94.
} 
Para Prieto Sanchís, y lo compartimos, la declaración de culpabilidad asociada a una sanción penal tiene un efecto estigmatizador sobre el honor de la persona "que no está considerado dentro de la pena legalmente considerada. A mayor abundamiento, los juicios paralelos suponen una penalización social anticipada, y por lo mismo, son parte de un proceso criminalizador, aunque se utilicen modos condicionales y palabras del tipo 'presunto', y en la medida que la publicidad es mayor, esta situación de 'pena anticipada' se exacerba, lo que puede afectar varios bienes jurídicos y derechos constitucionales protegidos, como la honra y el honor, el derecho a un juicio justo, la privacidad e intimidad, entre otros, lo que será especialmente grave para los casos en que no haya coincidencia entre lo que exprese el medio y el tribunal" ${ }^{44}$.

Estimamos que en ningún caso la publicidad recaída sobre una sentencia condenatoria ejecutoriada puede afectar irreversiblemente el derecho del delincuente a la resocialización y rehabilitación, que bajo los sistemas jurídicos contemporáneos debe ser el principal objetivo de la pena. Los objetivos de prevención general deben ser considerados ilegítimos como motivación principal (por ser contrarios al concepto de dignidad humana y al imperativo kantiano), por lo que siempre deberán estar mediatizados por el principio de legalidad y un adecuado juicio de ponderación.

Para terminar este apartado, sostendremos que los anticipos de inocencia realizados por la prensa constituyen una situación completamente distinta, aun cuando son hechos con sesgo, pues ello no sería más que el respeto activo de un principio constitucional: la presunción de inocencia ${ }^{45}$.

\section{Motivaciones tras los juicios paralelos y posibles medidas para reducir su impacto}

No siempre podrá sostenerse que los efectos nocivos que provoca la información sobre asuntos judiciales pendientes hayan sido deseados por quienes las emiten, sobre todo habiendo diversos emisores y opiniones. Sin embargo, hay y habrá casos en que es posible imaginar motivaciones específicas para montar una campaña mediática, cuyos objetivos son, en ocasiones, gravemente contrarios al ordenamiento institucional y por lo mismo ameritan una especial atención y regulación.

\footnotetext{
${ }_{44}$ Prieto (1997), p. 231. De acuerdo con Gimeno: "Una publicidad excesiva aumenta de manera importante el reproche social por el delito, de forma que el inculpado sufre un mayor escarnio" y agrega que puede afectar también el derecho a presunción de inocencia. Gimeno (1997), p. 31.

${ }^{45}$ Latorre (2002), p. 105.
} 
En muchos casos observados en la práctica profesional, esta realidad ha vuelto obligatorio el diseño de estrategias para un escenario doble: legal y comunicacional. Muchas veces ambos se consideran como decisivos y están a cargo de distintos grupos de especialistas.

Entre las razones e intereses más relevantes que pueden motivar un "juicio mediático" señalaremos las siguientes ${ }^{46}$ :

1. Interés en presionar al Tribunal, aumentando los costos sociales o frente a la opinión pública, de fallar en un sentido u otro. Esta presión puede ser coordinada entre una de las partes y el medio.

2. Interés de provocar en la opinión pública una idea diferente respecto a la culpabilidad o inocencia de una persona que la señalada por la sentencia judicial, o de obtener un determinado beneficio de cualquier tipo por vía extraprocesal (presiones para negociar, pérdida de imagen, etc. $)^{47}$.

3. Influir en la opinión pública para dañar o beneficiar la imagen de una persona, generalmente una figura pública o un político.

4. Interés de realizar una verdadera justicia paralela, estimulada por la crisis de confianza en los tribunales, la demora en la aplicación de justicia, la sensación de impunidad o agravio que en una víctima pueda existir, entre otras $^{48}$.

La rapidez y la desregulación de las investigaciones periodísticas puede favorecer su percepción como un mecanismo mucho más efectivo para establecer culpabilidades ${ }^{49}$, y sobre todo, la verdad, considerando que al juez

\footnotetext{
46 JUANES (2007), p. 64.

47 En la Instrucción 3/1993 del Ministerio Fiscal, de 16 de marzo, se señala que "a las razones de naturaleza material, en los últimos años, la duración de los juicios se ha visto afectada por 'otra causa de carácter especial, a saber, la rentabilidad extra procesal de un litigio prolongado en demasía y objeto de continuo tratamiento informativo'".
}

${ }^{48}$ Orenes señala que la negativa valoración de que goza la justicia se vincula a que es percibida "como un poder oscuro, secreto e incomprensible" y al "corporativismo existente entre los miembros del poder judicial y su estrecha vinculación, en ocasiones, al juego de los partidos políticos". Orenes (2008), p. 95. El estudio o Informe General "Barómetro interno de opinión de la abogacía española 2013", de 2013, destaca que el 74\% de los abogados define como mala o muy mala la forma en que actualmente funciona la justicia de España, aunque un $77 \%$ considera que ello se debe a la forma en que está organizada y no a las personas que la componen. Asimismo, se destaca que un $67 \%$ estima que los jueces saben preservar su independencia. "Barómetro interno de opinión de la abogacía española 2013", Informe General, 31 de enero de 2013.

49 En los Ilamados juicios paralelos "no resulta infrecuente que aparezcan y se analicen todo tipo de documentos y fuentes documentarias, algunas de ellas, desechadas en el propio proceso por no reunir los requisitos mínimos de accesibilidad procesal". HeRnÁndez (2001), p. 75. Ver también HeRnÁNDEZ (2000), pp. 117-132. Al respecto, Bravo señala críticamente que existe una contradicción entre el proceder de los tribunales y el de los medios que debiera ser ajustado, porque mientras por un lado "los tribunales anulan todos los días confesiones obtenidas con vulneración de derechos 
penal no le ha sido encomendada su búsqueda, sino solo afirmar o negar la calidad de la pretensión acusatoria ${ }^{50}$, en un proceso regulado y formal que no tiene la capacidad novelesca que puede dar la prensa a los mismos hechos ${ }^{51}$.

5. Interés de los medios de comunicación de aumentar sus ventas por medio de noticias de alto impacto y dramatismo, para obtener con ello un beneficio económico. Un aspecto delicado de esta situación es que la búsqueda de la primicia noticiosa (insumo o materia prima clave) podría Ilevar incluso al pago por este tipo de informaciones a quienes primero acceden a ellas (policías, jueces, abogados, etc.). El abordaje de este asunto es difícil fuera de las prácticas profesionales, sus códigos deontológicos, o las exigencias del público consumidor, pues el beneficio constitucional que recae sobre la difusión de información de interés público beneficia de modo casi idéntico a la prensa como industria del entretenimiento y como actividad lucrativa.

6. Interés de algunas autoridades de mostrar una imagen de eficiencia ${ }^{52}$.

Pese a que la jurisprudencia señala que la Constitución brinda "cierto grado de protección" 53 frente a los juicios paralelos, no hay en el ordenamiento jurídico una estructura de protección adecuada para evitarlos ni para evitar sus efectos perniciosos, situación que se repite a nivel global.

En parte la causa de ello es que la expresión "cierto grado" debe entenderse como una protección limitada y eventual, circunstanciada, sujeta a ponderación entre los derechos asociados al debido proceso y a los de libertad de expresión e información. Por ello, es correcto decir que habrá protección

por supuestos de tortura o, sencillamente, porque proceden de una mala información de derechos o del pinchazo de un teléfono realizado con una deficiente autorización judicial", la prensa goza de un estatuto laxo y opuesto, agregando que el mismo esquema constitucional no debiera permitir a los medios convertirse en una excepción al régimen de garantías establecido para todos. Bravo (2012), p. 60.

50 En contra, LóPEZ (2006), p. 102.

51 RodríGuez y otros (1985), p. 194.

${ }^{52}$ Roxin afirma que "la autoridad que persigue el crimen, sobre todo la policía, tiene interés en demostrar los éxitos obtenidos, sobre todo cuando se trata de un asunto de interés público (...) en casi todos los supuestos los medios de comunicación dependen de dicha información, porque no disponen de otras fuentes". Roxin (1999), p. 89. Según Marín, muchas veces los jueces y fiscales son los que informan a la opinión pública, a veces en cumplimiento de una labor social, aunque sea anónima. Luego agrega que "otros, sin embargo, filtran sumarios para justificar medidas que de otra manera podrían parecer injustas o que pueden no ser muy bien interpretadas". Marín (2012), p. 215.

${ }^{53}$ STC 136/1999, FJ 8 (por todas las citas). 
contra los juicios paralelos, aunque no podrá anticiparse el grado de la misma, que dependerá de los factores propios de cada caso ${ }^{54}$.

Cabe señalar que esta solución nos muestra una vez más la imposibilidad de dar plena satisfacción a todos los intereses involucrados. Si la protección dada a la imparcialidad fuera absoluta, como lo planteaba la doctrina del mínimo perjuicio, parcialmente vigente en Inglaterra antes del caso Sunday Times $^{55}$, no existiría la posibilidad real de informar respecto de procesos en curso en forma legítima. Por tanto, cierto grado de lesión deberá aceptarse para permitir la realización de los objetivos propios de la publicidad procesal y de la libertad de información.

De todos modos, se han planteado una serie de propuestas que buscan minimizar estos perjuicios. Algunos propician perfeccionar el ordenamiento vigente, especialmente allí donde las instituciones han quedado obsoletas (secreto de sumario ${ }^{56}$, causas legales de abstención y recusación ${ }^{57}$, entre otras), privilegiando la vía de las regulaciones específicas y minimalistas por sobre las generales ${ }^{58}$.

Asimismo, se ha planteado mirar el derecho comparado e introducir figuras similares a las ofrecidas por el contempt of court, típica de la órbita anglosajona y recientemente reformulada luego de la sentencia de la $\mathrm{CEDH}$ sobre el caso Sunday Times. Se ha dicho que ofrece mayor flexibilidad para proteger la imparcialidad y autoridad del Poder Judicial que las herramientas tradicionalmente utilizadas en el mundo continental ${ }^{59}$.

Otra forma de abordaje es desde el ámbito de la regulación de la libertad de expresión y abarca desde exigencias de diligencia debida y propiedad en

\footnotetext{
${ }_{54}$ ATC 195/1991, FJ 6, reconoce la posibilidad de que el derecho a un Tribunal independiente sea afectado a causa de las presiones desatadas por los medios de comunicación, por lo que puede ser protegido. La STC 136/1999, FJ 8, señala que el criterio sentado en el ATC 195/1991 es que la protección que la Constitución dispensa frente a los juicios paralelos "se encuentra contrapesada (...), externamente, por las libertades de expresión e información que reconoce el art. 20 C.E. (...); internamente (...). De ahí que, si bien la salvaguarda de la autoridad e imparcialidad del poder judicial puede exigir la imposición de restricciones en la libertad de expresión (art. 10.2 de la Convención Europea de Derechos Humanos), ello no significa, ni mucho menos, que permita limitar todas las formas de debate público sobre asuntos pendientes ante los Tribunales (STEDH caso Worm, párrafo 50) (...)".

${ }^{55}$ CEDH No 6538/74, Sunday Times v. Reino Unido, de 26 de abril de 1979.

56 Rodríguez (1999), pp. 246 y ss., citada por Orenes (2008), p. 280.

57 Ver STC 60/1995 y STC 162/1999. Calvo (2009), p. 34, citando el Auto Pleno 394/2006, de 7 de noviembre, FJ 4.

${ }^{58}$ Roxin (1999), pp. 77 y ss.

59 Orenes (2008), p. 95. Sobre la figura del desacato o "contempt of court", ver Fayos (1987), pp. 911-918,

y Caviedes (2008). ValldeCabres (2004) dedica un capítulo especial a este tema.
} 
el uso del lenguaje, hasta criterios de filmación y transmisión de audiencias orales, especialmente televisadas ${ }^{60}$, pues se ha señalado que la sola presencia de cámaras en los juicios puede afectar especialmente a quienes participan en ellos ${ }^{61}$.

Desde otra perspectiva, dada la complejidad de la materia y las múltiples órbitas de relaciones afectadas, Gimeno Sendra ha propuesto distinguir entre medidas fundadas en los diferentes momentos procesales, en las personas o en el bien jurídico que se busque proteger ${ }^{62}$.

La distinción por momentos procesales permite focalizarse en sus necesidades específicas. Evidentemente, durante la etapa de investigación se permitirán mayores restricciones a la publicidad ${ }^{63}$, mientras en la etapa del juicio oral el principio de publicidad se verá potenciado por los derechos de defensa y la libertad de información ${ }^{64}$.

${ }^{60}$ Una buena sistematización de las normas y experiencias al respecto se encuentran en NAVARRO (2011), pp. 115 y ss.

${ }^{61}$ STC 57/2004, FJ 4: "No está excluido que la captación de imágenes en el proceso pueda producir una viva impresión en los que intervienen en el mismo. La instalación y utilización de cámaras de captación de imágenes puede, sin duda, suscitar efectos intimidatorios, por ejemplo, sobre los procesados en un juicio penal, sus defensores y los testigos, lo que podría ser suficiente para excluir la presencia de aquéllas (STC 65/1992, FJ 2). Por otra parte, en algunas circunstancias, la impresión de realidad que va asociada a la imagen visual podría favorecer especialmente el desarrollo de los que se han denominado 'juicios paralelos', frente a los que 'la Constitución brinda un cierto grado de protección (...) en la medida en que pueden interferir el curso del proceso' (ATC 195/1991, de 26 de junio, FJ 6). Y la simple instalación de los normalmente complejos medios técnicos necesarios para captar y difundir estos mensajes podría, por sus exigencias de tiempo y espacio, en determinados supuestos, perjudicar el ordenado desarrollo del proceso indispensable para la correcta administración de justicia. Si, como este Tribunal ya ha declarado, los derechos del art. 24 CE pueden constituir límites al ejercicio de la libertad de información (ATC 195/1991, de 26 de junio, FJ 6), es razonable afirmar que esos límites a los derechos del art. 20.1 d) CE podrán llegar tanto más lejos cuanto mayor sea el grado del perjuicio que éstos puedan suponer a los derechos de defensa; y que ese grado de perjuicio, sin duda, se intensifica en el caso de la captación y difusión de información visual". En forma idéntica se pronuncia la STC 56/2004, de 19 de abril de 2004, referida al mismo tema. En el mismo sentido de crítica a la transmisión televisiva, VerGER (1996), pp. 214-216.

${ }^{62}$ En esto seguimos parcialmente a Gimeno, quien plantea observar como criterios el procedimental (por ejemplo, si la actuación es pública o secreta), el subjetivo o personal (determinando si nos encontramos frente a una persona pública o privada) y el material (que supone un balance entre los derechos y bienes afectados). GIMENO (1999), pp. 295-306.

${ }^{63}$ El Anteproyecto de la Ley de Enjuiciamiento Criminal, de 27 de julio de 2011, señala que la actividad investigadora tiene carácter preparatorio (más que judicial) y que una transmisión indiscriminada de su contenido a la opinión pública supone un grave atentado para el derecho de presunción de inocencia (p. 54). Por ello, la publicidad tiene distintos niveles según la fase del juicio (máxima en materia de juicio oral y mínima en la etapa investigadora).

64 ATC 195/1991, FJ 6: “(...) una vez decretada la apertura del juicio oral, rige el principio de publicidad absoluta e inmediata, en tanto que garantía procesal tendiente a salvaguardar el derecho 
El criterio vinculado a la persona permite dar un tratamiento diferente a las expresiones emitidas por cada actor, tanto dentro o fuera del juicio. Los múltiples criterios posibles de utilizar en estas materias nos impiden desarroIlarlo en este espacio ${ }^{65}$. Aunque cabe recordar, por ejemplo, que el Tribunal Europeo de Derechos Humanos ha llegado a decir que es esperable que los abogados contribuyesen a la adecuada administración de justicia y a mantener la confianza en los tribunales, limitando la posibilidad de realizar comentarios críticos en público ${ }^{66}$. Sobre la base de esta lógica, se han validado pequeñas multas impuestas a un abogado por sus declaraciones a la prensa ${ }^{67}$.

Los jueces cuentan con una mayor protección frente a las agresiones mediáticas que otras figuras públicas ${ }^{68}$, debido a la existencia de un interés general, tutelado legalmente ${ }^{69}$, de favorecer la credibilidad y autoridad del Poder Judicial y de los Tribunales de Justicia ${ }^{70}$, así como su imparcialidad ${ }^{71}$.

fundamental a un proceso público del art. 24.2, así como instrumento para fortalecer la confianza del pueblo en la independencia e imparcialidad de sus tribunales". Una vez dictada la sentencia, la posibilidad de afectar la imparcialidad del juzgador o los derechos procesales de las partes para ese caso concreto será nula, por lo que las medidas que se establezcan serán más escasas y deberán fundarse en otro tipo de consideraciones (honor, derecho al olvido, etc.).

${ }^{65}$ Es interesante consignar que en el I Encuentro Jueces-Periodistas la mayoría de los jueces señaló que deberían imponerse limitaciones a la libertad de información y a la publicidad procesal por razón de la persona o la naturaleza del delito; en cambio, la mayoría de los periodistas opina lo contrario (pregunta 19).

${ }^{66}$ CEDH No 31611/96, Nikula v. Finlandia, de 21 de marzo de 2002, párrafos 45, 46 y 48.

${ }_{67}$ CEDH No 56/1997/840/1046, Schöpfer v. Suiza, de 20 de mayo de 1998, párrafos 29-34. En un sentido similar se pronunció la CEDH en el caso Zihlmann v. Suiza. El Tribunal Constitucional ha tenido en general una posición similar: STC 107/1988, FJ 3; y STC 173/1995, FJ 6, 7 y 8.

${ }^{68}$ En este sentido, la CEDH ha sido clara al señalar que "la prensa representa uno de los medios de los que disponen los responsables políticos y la opinión pública para verificar que los jueces ejercen sus altas responsabilidades de conformidad con el fin constitutivo de la misión que se les ha confiado". CEDH No 15974/90, Prager and Oberschlick v. Austria, de 26 de abril de 1995, párrafo 34. CEDH No 13778/88, Thorgeir Thorgeirson v. Islandia, de 26 de junio de 1992. Ver también VALLDECABRES (2004), p. 266.

${ }^{69}$ Art. 10 inciso 2 Carta Europea de Derechos Humanos.

${ }^{70}$ Es discutible la tesis que afirma que los jueces se han expuesto voluntariamente a la crítica por el solo hecho de asumir una función pública. En este punto, el elemento principal del análisis no puede ser la evidente voluntariedad de asumir el cargo de juez, sino las necesidades institucionales que se esperan de esta importante función y las condiciones que contribuyen a su mejor desempeño. Ver STS de 14 de julio de 1999 y STS de 27 de septiembre de 1999, referidas al "caso Hormaechea" y a la valoración de las declaraciones del Presidente del Tribunal.

71 En la misma línea, el Tribunal Europeo de Derechos Humanos ha señalado que los jueces deben evitar expresiones que puedan afectar su autoridad o imparcialidad, cuestionando especialmente la participación de jueces en ruedas de prensa sobre asuntos pendientes y validando las sanciones 
Ello justifica una serie de limitaciones al ejercicio de la libertad de expresión de los jueces, especialmente para replicar y controvertir públicamente cualquier información que los afecte ${ }^{72}$. La opinión mayoritaria de la doctrina considera que los jurados, por su ausencia de entrenamiento, menor cultura jurídica y mayor proximidad con la comunidad, son especialmente sensibles a las presiones mediáticas, lo que justifica su especial protección ${ }^{73}$.

Pese a que en muchas ocasiones se ha reiterado el deber del Estado de facilitar el acceso a las informaciones relativas al ámbito judicial ${ }^{74}$, también se ha llegado a casos en que se ha anulado sentencias por dictarse ellas en un ambiente hostil ${ }^{75}$.

disciplinarias impuestas por filtrar informaciones sobre proceso sub iudice. CEDH No 26601/95, Leiningen-Westerburg v. Austria, de 20 de enero de 1997. CEDH № 28396/95, Wille v. Liechtenstein, de 28 de octubre de 1999, párrafos 60 y 64.

72 STC 46/1998, FJ 5. STC 162/1999, FJ 9. El art. 396 de la Ley Orgánica del Poder Judicial (LOPJ) establece un deber de sigilo respecto de hechos o noticias referidos de los que hayan tenido conocimiento en el ejercicio de sus funciones (STC 64/2001, FJ 2), así como limita la posibilidad de enviar felicitaciones o censuras a otros poderes públicos o corporaciones oficiales, sirviéndose o invocando la condición de juez (artículo 418.3 de la LOPJ). Esta limitación es permanente y general, ya que la condición de juez no solo se refiere a una actividad laboral, sino a un rol social que no puede dejarse de lado para invocar los derechos de un ciudadano común. El único caso que merecería dudas sería la crítica, positiva o negativa, realizada por el juez a otras sentencias. También se ha dicho que, por el carácter más político del TC, sus integrantes deben soportar mayor crítica que un juez ordinario (STC 173/1995, FJ 6). Hay quienes han cuestionado el hecho de que, frente a este tipo de situaciones, y en especial, frente a los juicios paralelos, se haya reaccionado buscando establecer límites a la libertad de expresión de los jueces (impidiéndoles participar en programas de televisión, dar ruedas de prensa, entre otras). De VeGA (1998), p. 68.

${ }^{73}$ CEDH No 53886/00, Tourancheau et July v. Francia, de 24 de noviembre de 2005. En el mismo sentido se pronuncia el principio 10 y la exposición de motivos de la Recomendación (2003) 13 del Consejo de Europa. Verger Grau señala que muchas personas creen que los miembros del jurado se dejan influir en mayor medida por los medios de comunicación que por las pruebas presentadas en audiencias. Verger (1996), pp. 200 y ss. En contra, Vives, Valldecabres y Alonso, quienes Ilaman la atención sobre la libertad que implica no estar atado a una carrera funcionaria, que pueda depender de su comportamiento y fallo en un determinado caso (Orenes (2008), p. 276; y VAlLdeCABRES (2004), pp. 274 y ss.).

${ }^{74}$ A modo de ejemplo, la Instrucción 3/2005 del Ministerio Fiscal señala expresamente que a los fiscales, pese a ser parte del juicio penal, les corresponde facilitar el acceso de la prensa a los asuntos judiciales, asumiendo que, si ello igualmente sucederá, es mejor que lo haga por intermedio de un organismo público que pueda velar por la calidad, completitud y neutralidad de la misma.

75 Sheppard v. Maxwell, 384 U.S. 333 (1966). La sentencia reconoce la importancia de que el juicio se desarrolle en un ambiente libre de influencias externas, señalando que quienes participan en el proceso de administrar justicia (fiscales, abogados, testigos, personal, etc.) están obligados a contribuir con este propósito. Por ello, su relación con la prensa puede ser regulada y, en los casos que corresponda, sometida a sanciones, sin perjuicio del derecho de la prensa a informar sobre los asuntos judiciales y de la comunidad a contar con ella. 
Por otro lado, siendo evidente que sus actuaciones pueden ser objeto de crítica y publicidad, los jueces y demás funcionarios vinculados con la Administración de Justicia deberán actuar con máxima prudencia y cautela, en ocasiones superando incluso el ámbito meramente judicial, como quedó por ejemplo demostrado en el caso "Perna con Italia", en el que el Tribunal Europeo de Derechos Humanos señaló que un funcionario judicial que milita en un partido se expone por esa sola causa a cuestionamientos y sospechas, las que pueden afectar la imagen y autoridad del poder judicial ${ }^{76}$.

Otra situación singular es de los testigos y peritos, que normalmente participan en procesos judiciales que les son ajenos en cumplimiento de una exigencia normativa ${ }^{77}$. No obstante ello, sus declaraciones son de tal relevancia que es fundamental protegerlas de influencias y presiones mediáticas, lo cual es consistente con uno de los objetivos centrales del derecho procesal moderno: la adecuada protección de las víctimas y la minimización del impacto negativo que importa cualquier proceso $^{78}$.

Al final del día, el criterio más relevante parece ser el vinculado a la naturaleza del bien jurídico protegido, sobre todo por el hecho de que todo conflicto puede discutirse y resolverse sobre la base de los derechos fundamentales involucrados, máxime allí donde no hay reglas. De hecho, cualquier solución normativa, por específica que sea, será el resultado de un juicio de ponderación realizado en sede legislativa, muchas veces basado en criterios establecidos previamente por la jurisprudencia.

Pero es claro que la relevancia de los asuntos tratados y su masividad no aconsejan dejarlos entregados sin más al criterio jurisdiccional, sino que aconsejan el estudio y dictación de reglas que canalicen la valoración de los elementos de los casos tipo, sin perjuicio de su corrección y adaptación a cada caso particular podrá siempre realizarse por la vía de la ponderación judicial.

Las formas utilizadas para defender la imparcialidad, por ejemplo, son muchas y van desde el establecimiento de ciertos secretos transitorios, al establecimiento de sanciones penales e incluso, en los casos más extremos y problemáticos, a la suspensión del procedimiento, el cambio de jueces o

${ }^{76}$ CEDH No 48898/99, Perna v. Italia, de 25 de julio de 2001, párrafo 41. En el párrafo 42 se señalaba que la militancia del funcionario cuestionado era pública y notoria, lo que agravaba la situación. Murray v. Brancato, 264 App. Div. 862, decidida el 4 de marzo de 1943.

77 Art. 118 CE, arts. 420 de la Ley de Enjuiciamiento Criminal y 463 y 556 del Código Penal.

78 Sobre este punto ver Moreno (1998), p. 60; Fuentes (2007), p. 979; Gimeno (2010), pp. 37-39; Oromívall-Llovera (2012) (al tratar los derechos y garantías procesales de la víctima en Europa). Asimismo, la Directiva 2012/29 y 2005/20 UE, la Exposición de Motivos de la LO 19/1994. Cabe destacar que esta preocupación era masivamente ignorada dentro de la doctrina procesal tradicional. 
incluso la anulación de la sentencia emitida en un clima mediáticamente cargado $^{79}$. Resulta evidente que la relevancia del bien protegido y la intensidad de las medidas requieren normas y facultades claras y precisas que nunca podrán ser suplidas por la creatividad judicial.

Dentro de esta línea de acción se han planteado una serie de medidas, como por ejemplo la posibilidad de realizar juicios a puerta cerrada o con acceso restringido a la prensa, mayores facultades judiciales para la protección del proceso y de los derechos de las partes ${ }^{80}$, la publicación de sentencias editadas (nombres de las víctimas, testigos, etc.), facilitaciones comunicativas por parte de tribunales y del Ministerio Público, mayores facultades para el amparo judicial, establecimiento de ciertos tipos penales efectivos (para quienes realicen filtraciones o a sabiendas difundan informaciones declaradas bajo reserva, realicen agresiones mediáticas, etc.), adoptar medidas para acelerar los resultados de la actividad judicial ${ }^{81}$, hasta las prohibiciones transitorias de informar. Sobre este último punto, cabe destacar la importancia de la brevedad y excepcionalidad de la medida, que en ningún caso alcanza toda la etapa de sumario. Cabe recordar el caso de la desaparición de Marta del Castillo, por ejemplo, donde los hechos ocurrieron en enero de 2009 y la apertura del juicio oral comenzó a mediados de 2012. No era factible mantener en el secreto la información por un período tan prolongado ${ }^{82}$.

Finalmente, se han planteado soluciones que van más allá del plano regulativo, que muchas veces requieren un profundo cambio de mentalidad. Por ejemplo, el Poder Judicial deberá mostrar una actitud más colaborativa y abierta hacia la prensa e incluso hacia la crítica, facilitando el acceso a

\footnotetext{
79 Sheppard v. Maxwell, 384 U.S. 333 (1966).

80 STC 187/1999, FJ 10, señala que "advertidas todas estas circunstancias, y sin prejuzgar el fondo del asunto, el Juez de Instrucción consideró deber suyo proteger a los eventuales perjudicados con la revelación de aquella información, con arreglo a lo dispuesto en el art. 13 LECrim., y a las partes en el proceso judicial frente a aquello que pudiese perturbar la adecuada y correcta marcha del proceso judicial con indeseables 'juicios paralelos' en los medios de comunicación, que bien podrían conculcar el derecho a la tutela judicial efectiva (art. 24.1 C.E.) y el derecho a un proceso con todas las garantías (art. 24.2 C.E. STC 171/1990, FJ 9, ATC 195/1991, FJ 6; Sentencias de la CEDH caso Sunday Times I, de 26 de abril de 1979, Observer y Guardian, de 26 de abril de 1991)".

${ }^{81}$ En el estudio Centro de Investigaciones Sociológicas (CIS) Barómetro número 2861, de febrero de 2011, un 77\% señaló que el primer problema de la justicia era su lentitud. Sin embargo, el 5 de diciembre de 2013 en Madrid, la Fundación Wolters Kluwer presentó el Informe 2013 de la Actividad Judicial elaborado por el Observatorio de la Actividad de la Justicia, donde se señala que los indicadores de calidad de los tribunales mejoran por segundo año, acumulando casi un 5\%. Entre los factores que explican lo anterior está el descenso de la carga de trabajo y la mayor celeridad en la resolución de los procedimientos. Cabe señalar que en años anteriores (2008-2009) la tendencia era la opuesta.

82 Peral (2012), p. 154.
} 
la información oportuna, clara y de calidad, ya sea a través de gabinetes de acceso a la información, páginas web, la emisión de comunicados periódicos de la evolución del proceso a través de oficinas de prensa, la redacción de sentencias mejor fundadas y comprensibles para el público general, entre otras $^{83}$. Asimismo, la protección constitucional reforzada de la libertad de expresión e información podrá asociarse a un aumento de los estándares de cuidado y diligencia exigidos, al menos cuando puedan afectarse derechos tan relevantes como la presunción de inocencia ${ }^{84}$.

A nivel de medios de comunicación, un importante aporte podría venir de la mano del autocontrol y de códigos deontológicos ${ }^{85}$ realmente efectivos, así como de la mejor formación de los periodistas en materias legales, el dejar públicamente establecido que la visión y postura del caso, que se está ofreciendo por la prensa, es parcial y subjetiva ${ }^{86}$, entre otras.

\section{Conclusiones}

1. Las informaciones y opiniones sobre los hechos de alto impacto (sean o no constitutivos de delito) y sobre asuntos judiciales son una necesidad, tanto de la publicidad procesal como de la libertad de información, y cuentan con una protección constitucional especialmente vigorosa.

Por tanto, desde cierto punto de vista, la difusión realizada por la prensa de pruebas, hechos delictuales, desarrollo del proceso y probabilidades de que los intervinientes sean declarados culpables o inocentes, en forma paralela al trabajo judicial, es fundamental tanto para la garantía del juicio justo como para el proceso democrático.

2. No obstante lo anterior, la expresión "juicio paralelo" o "justicia mediática" se encuentra ampliamente difundida y utilizada con una connotación

\footnotetext{
83 Orenes reporta una tradicional difícil relación entre jueces y medio, que debería evolucionar hacia una cultura más democrática y abierta al escrutinio, la publicidad y la crítica. Orenes (2008), p. 95. Como muestra de lo anterior, STC 56 y 57, ambas de 2004, o el CGPJ en su comunicado del 2 de enero de 1995.

${ }^{84}$ STC 219/1992, FJ 5; STC 28/1996, FJ 3; STC 54/2004, FJ 3; STC 1/2005, FJ 5.

${ }^{85}$ En el Código Deontológico de la Federación de Asociaciones de Prensa de España, aprobado en Asamblea Ordinaria celebrada en Sevilla el 27 de noviembre de 1993, Principio 5, se indica que "el periodista debe asumir el principio de que toda persona es inocente mientras no se demuestre lo contrario y evitar al máximo las posibles consecuencias dañosas derivadas del cumplimiento de sus deberes informativos. Tales criterios son especialmente exigibles cuando la información verse sobre temas sometidos al conocimiento de los Tribunales de Justicia. El periodista deberá evitar nombrar en sus informaciones a los familiares y amigos de personas acusadas o condenadas por un delito, salvo que la mención resulte necesaria para que la información sea completa y equitativa".

${ }^{86}$ Revista del Poder Judicial, Número Especial XVII (1999), pregunta 14.
} 
negativa. No estando claro su contenido, parece más útil identificar aquellas acciones comunicativas e informaciones que implican afectaciones ilegítimas a bienes jurídicamente protegidos, lo que a su vez facilitará la compatibilización, en la mayor medida posible, de los derechos en juego.

3. El trabajo periodístico y el judicial tienen objetivos y estatutos jurídicos diferentes, por lo que más allá de la coincidencia de objeto (investigar y opinar sobre posibles delitos y asuntos judiciales) no es extraño que difieran en un sinnúmero de materias ${ }^{87}$. $\mathrm{Ni}$ a los tribunales corresponde satisfacer el derecho de la comunidad a ser informado, ni a la prensa perseguir la responsabilidad legal de una persona ${ }^{88}$, por lo que los requisitos del debido proceso solo pueden reclamarse al Poder Judicial.

4. Lo recién dicho no pretende negar que ciertas informaciones y opiniones sean molestas, entren en conflicto o se muestren ilegítimas, el Estado deberá tomar todas las acciones que permitan restringirlas, desincentivarlas, evitarlas o reducir sus efectos negativos ${ }^{89}$.

5. Tanto el Tribunal Constitucional como el TS han hecho referencia expresa a los juicios paralelos en algunas de sus sentencias, desarrollando una doctrina que en lo sustancial parece uniforme. Especialmente ellas se han referido a la capacidad de dichas acciones mediáticas para afectar la imparcialidad de los Tribunales, tanto en forma estricta como en cuanto a la idea que de ella conviene que tenga la ciudadanía (autoridad, respeto, confianza). Cuando las informaciones alcanzan este nivel de afectación, se conculca el derecho a un proceso con todas las garantías, bastando para probar lo anterior "la probabilidad fundada de que tal influencia ha tenido lugar"

6. Las motivaciones que hay detrás de un juicio paralelo pueden ser muchas y no siempre obedecerán a un dolo o voluntad, debido a la multiplicidad de actores involucrados y de circunstancias. Pueden ir desde el ánimo expreso de influir en magistrados, hasta anticipar una condena por vía extrajurisdiccional, o simplemente, captar la atención de la opinión pública con el objeto

\footnotetext{
${ }^{87}$ CEDH No 6538/74, Sunday Times v. Reino Unido, de 26 de abril de 1979, párrafo 65. (Mutatis mutandis, sentencia CEDH Nos. 5095/71, 5920/72, 5926/72, Kjeldsen, Busk Madsen and Pedersen v. Denmark, de 7 de diciembre de 1976, párrafo 52.

${ }^{88}$ CEDH No ${ }^{\circ}$. 5095/71, 5920/72, 5926/72, Kjeldsen, Busk Madsen and Pedersen v. Denmark, de 7 de diciembre de 1976, párrafo 55.

89 STC 187/1999, FJ 10. En un sentido similar, STC 136/1999, FJ 8, CEDH No 6538/74, Sunday Times v. Reino Unido, de 26 de abril de 1979, párrafo 63; CEDH № 19983/92, De Haes and Gijsels v. Bélgica, de 24 de febrero de 1997, párrafo 37, y CEDH № 22714/93, Worm v. Austria, de 29 de agosto de 1997, párrafos 50 y 54.

90 STC 136/1999, FJ 8, citando la sentencia CEDH № 22714/93, Worm v. Austria, de 29 de agosto de 1997, párrafo 54 (por ambas citas).
} 
de aumentar las ventas e ingresos de la empresa periodística, mediante la utilización de un insumo de bajo costo, de alta carga dramática y protegido intensamente por la Constitución.

7. No existen respuestas claras o definitivas sobre la forma de generar soluciones en esta materia, por la importancia de los bienes jurídicos en juego y la multiplicidad de actores, relaciones y circunstancias involucradas. Sin embargo, se han planteado una serie de medidas normativas y extrajurídicas, que van desde la modernización de los procedimientos y el establecimiento de excepciones justificadas a la lógica de la publicidad, hasta campañas educativas, uso de mayores estándares éticos y profesionales en la entrega informativa, entre otras.

Cada una de las situaciones problemáticas vinculadas a los "juicios paralelos" están clara y profundamente conectadas con derechos protegidos constitucionalmente y pueden expresarse como tales, encontrando en la ponderación un extraordinario mecanismo de solución, vinculado al caso concreto y a todas sus circunstancias. Pero esta realidad no obsta a que el ejercicio de estos derechos sea especificado por vía normativa (ponderación realizada en sede legislativa), lo que permite aumentar la certeza de todos los actores jurídicos y simplificar una serie de situaciones (sin perjuicio de que, cuando las circunstancias lo exijan, los tribunales ejerzan su capacidad de interpretar y corregir dichas normas utilizando un criterio ponderativo).

8. Todas las medidas que puedan plantearse deberán compatibilizar, en la mayor medida posible, la necesidad democrática de una comunidad en cuanto a disponer de información sobre el funcionamiento de los órganos del Estado y los asuntos de interés público, el ejercicio de las libertades expresivas e informativas y las garantías y necesidades propias de un juicio justo. En particular, es fundamental que los tribunales sean vistos como el lugar adecuado para resolver adecuadamente las controversias jurídicas dentro de la organización social ${ }^{91}$, evitando cualquier incentivo a utilizar la prensa con este propósito.

\section{Bibliografía CitADA}

Barbero Santos, Marino (1997): Prisión Provisional, detención preventiva y derechos fundamentales (Ediciones de la Universidad de Castilla, La Mancha).

91 ATC 195/1991, FJ 6 (citando a la CEDH No 6538/74, Sunday Times v. Reino Unido, de 26 de abril de 1979, párrafo 55). 
Bravo, Gabriela (2012): "Ponencia Magistral. Derecho a la información y populismo mediático", en: La presunción de inocencia y los juicios paralelos (Madrid, Editorial La Ley).

Bujosa, Lorenzo M. (2007): "Pruebas de referencia y garantías procesales", en: Diario La Ley, Madrid.

Calvo Sánchez, María del Carmen (2009): Control de la imparcialidad del Tribunal Constitucional (Barcelona, S.A. Atelier Libros).

Carnelutti, Francesco (1961): "La publicidad en el Proceso Penal", en: Carranza, Elías (coord.), Cuestiones sobre el Proceso Penal (Buenos Aires, Ediciones Jurídicas Europa América), pp. 125-143.

CARRILlo, Marc (2004): "Informar sobre juicios no es una cuestión graciosa", en: Diario El País, Madrid, 19 de junio.

Caviedes, Cristóbal (2008): El Contempt of Court, el Caso Sunday Times y la Incorporación de la Convención Europea de Derechos Humanos en Gran Bretaña: ¿Cambio en la Jurisprudencia? (Tesis para obtener el grado de Licenciado en Derecho, Pontificia Universidad Católica de Chile).

Cortés Bechiarelu, Emilio (2003): "Juicios paralelos y derechos fundamentales del justiciable", en: Anuario de la Facultad de Derecho (№ 21), pp. 123-151.

De Vega Ruiz, José Augusto (1998): Libertad de expresión, información veraz, juicios paralelos, medios de comunicación (Madrid, Editorial Universitas).

Espín Templado, Eduardo (1990): "En torno a los llamados juicios paralelos y la filtración de noticias judiciales", en: Revista del Poder Judicial ( $N^{\circ}$ Extraordinario 13 sobre Libertad de Expresión y Medios de Comunicación), pp. 123-130.

Fayos Gardó, Antonio (1987): "La Contempt of Court Act británica de 1981: el Desacato al Tribunal cometido por los medios de comunicación social", en: Revista Jurídica Española de Doctrina, Jurisprudencia y Bibliografía (No 3), pp. 911-918.

Fuentes Soriano, Olga (2007): "La protección de los derechos de la víctima", en: Gimeno Sendra, José Vicente (coord.), El Tribunal Supremo, Doctrina Legal y el Recurso de Casación: Estudios en Homenaje al Profesor Almagro Nosete. (Madrid, lustel), pp. 979-994.

Gimeno, Miguel Ángel (1997): “Consideraciones Jurídicas sobre los Juicios Paralelos", en: Informe sobre el Tratamiento del Juicio de Alcásser (Barcelona).

Gimeno Sendra, José Vicente (1998): Constitución y proceso (Madrid, Tecnos).

Gimeno Sendra, José Vicente (1999): "La sumisión del juez a la crítica pública", en: Revista del Poder Judicial (Número especial XVII: Justicia, información y opinión pública. I Encuentro Jueces-Periodistas), pp. 295-306. 
Gimeno Sendra, José Vicente (2010): Derecho Procesal Penal (Madrid, Ed. Colex).

HeRnández García, Javier (2000): “Juicios paralelos y proceso penal: Razones para una necesaria intervención legislativa", en: Revista de Derecho y Proceso Penal (Año 2000, № 3), pp. 117-132.

Hernández García, Javier (2001): "Justicia Penal y Medios de Comunicación: Los Juicios Paralelos", en: Pıcó y Junor, Joan, Problemas actuales de la justicia penal (Barcelona, Bosch), pp. 117-132.

Juanes Peces, Ángel (1999): "Los juicios paralelos", en: Revista del Poder Judicial (Número especial XVII: Justicia, información y opinión pública. I Encuentro Jueces-Periodistas).

Juanes Peces, Ángel (2007): "Los juicios paralelos. El Derecho a un proceso justo", en: Justicia y medios de comunicación (Madrid, Consejo General del Poder Judicial).

JuAnes PeCEs, Ángel (2012): “Independencia judicial y medios de comunicación”, en: La presunción de inocencia y los juicios paralelos (Madrid, Editorial La Ley).

Latorre Latorre, Virgilio (2002): Función jurisdiccional y juicios paralelos (Madrid, Civitas).

LÓPEz Ortega, Juan (2006): "Información y justicia: la dimensión constitucional del principio de publicidad judicial y sus limitaciones", en: Cuadernos de Derecho Judicial ( $N^{\circ} 16$, dedicado a Justicia y medios de comunicación), pp. 102-123.

Marín, Manuel (2012): "La presunción de inocencia y los juicios paralelos", en: La presunción de inocencia y los juicios paralelos (Madrid, Editorial La Ley).

Mezzanotte, Massimiliano (2009): Il Diritto All'oblio. Contributo Allo Studio Della Privacy Storica (ed. Collana della Facoltá di Giurisprudenza, Universita degli studi di Teramo, Edizioni Scientifiche Italiane).

Moreno Catena, Víctor (1998): "La protección de los testigos y peritos en el proceso penal español", en: Revista Penal (№ 4), pp. 58-67.

Navarro Marchante, Vicente J. (2011): El derecho a la información audiovisual de los juicios (Madrid, Centro de Estudios Políticos y Constitucionales).

Orenes Ruiz, Juan Carlos (2008): Libertad de información y proceso penal. Los límites (Pamplona, Aranzadi).

Oromívall-Llovera, Susana (2012): "Los derechos de la víctima en las reformas del proceso penal. Del olvido al resurgimiento", en: Revista La Ley Penal (No 98-99), pp. 6-18. 
Palermo, Patrizia (2010): “Diffamazione e dirittoall'oblio: equilibrio 'elastico' tra tutela penaledell'onore e diritto di cronacagiudiziaria", en: Revista Penale (Vol. 136), pp. 277-286.

Peral, María (2012): La presunción de inocencia y los juicios paralelos (Madrid, Editorial La Ley).

Prat Westerlindh, Carlos (2001): "Los juicios paralelos y la imparcialidad judicial", en: Revista Doctrina y Jurisprudencia (No 36).

Prieto Sanchís, Luis (1997): "Prisión Provisional y Medios de Comunicación", en: Barbero Santos, Marino (coord.), Prisión provisional, detención preventiva y derechos fundamentales (Colección Estudios Universidad de Castilla - La Mancha).

Pulido Quecedo, Manuel (2008): “La dimensión extraprocesal de la presunción de inocencia", en: Repertorio Aranzadi del Tribunal Constitucional (№ 19).

Quintero Olivares, Gonzalo (1990): "Libertad de Prensa y Protección de la Independencia e Imparcialidad Judicial", en: Revista del Poder Judicial ( $N^{\circ}$ Extraordinario 13 sobre Libertad de Expresión y Medios de Comunicación), pp. 385-402.

Rodríguez Bahamonde, Rosa (1999): El secreto de sumario y la libertad de información en el proceso penal (Madrid, Dykinson).

Rodríguez RAmOS, Luis (2002): "La verdad y las verdades en el proceso penal: ¿hacia una justicia 'dependiente' de los medios de comunicación?", en: Diario La Ley ( $N^{\circ}$ 5585, Editorial La Ley).

Rodríguez Ramos, Luis; Álvarez Pérez, Terenciano y Rodrícuez, Pedro (1985): "La publicidad del sumario", en: Libertad de expresión y derecho penal (Madrid, Edersa).

Roxin, Claus (1999): "El proceso penal y los medios de comunicación", en: Revista del Poder Judicial (No 55), pp. 73-94.

TiтıUM, Patrick (1999): "Libertad de información y Poder Judicial en el Convenio Europeo de Derechos Humanos", en: Revista del Poder Judicial (Número especial XVII: Justicia, información y opinión pública. Encuentro JuecesPeriodistas), pp. 361-372.

UnIÓN EUROPEA (2006): Libro verde de la Comunidad Europea sobre la presunción de inocencia (Bruselas, COM).

Valldecabres Ortiz, María Isabel (2004): Imparcialidad del juez y medios de comunicación (Madrid, Tirant lo Blanch).

Verger Grau, Joan (1996): "Los juicios paralelos y la presunción de inocencia con especial referencia al jurado", en: Gutiérrez-Alviz y Conradı, Faustino (ed.), 
La criminalidad organizada ante la justicia (Sevilla, Ediciones Universidad de Sevilla).

JURISPRUDENCIA CITADA

ATC 195/1991, de 26 de junio.

Caso Allenet de Ribemont, de 10 de febrero de 1995.

Caso M. Berns y J. Ewert contra Luxemburgo.

Caso Petra Krause (Suiza).

Caso X contra (Austria, R.F. y S.F.).

CEDH Zihlmann v. Suiza.

CEDH N ${ }^{0}$ 5095/71.

CEDH N N $^{0} 5920 / 72$.

CEDH N ${ }^{\circ} 5926 / 72$.

CEDH Kjeldsen, Busk Madsen and Pedersen v. Denmark, de 7 de diciembre de 1976.

CEDH N ${ }^{\circ}$ 6538/74, Sunday Times v. Reino Unido, de 26 abril de 1979.

CEDH No 13778/88, Thorgeir Thorgeirson v. Islandia, de 25 de junio de 1992.

CEDH No 15175/89, Allenet de Ribemont v. Francia, de 10 de febrero de 1995.

CEDH N ${ }^{\circ}$ 15974/90, Prager and Oberschlick v. Austria, de 26 de abril de 1995.

CEDH No 17419/90, Wingrove v. Reino Unido, de 25 de noviembre de 1996.

CEDH No 26601/95, Leiningen-Westerburg v. Austria, de 20 de enero de 1997.

CEDH No 19983/92, De Haes and Gijsels v. Bélgica, de 24 de febrero de 1997.

CEDH No 22714/93, Worm v. Austria, de 29 de agosto de 1997.

CEDH No 56/1997/840/1046, Schöpfer v. Suiza, de 20 de mayo de 1998.

CEDH No 26682/95, Sürek v. Turquía ( $N^{\circ} 1$ ), de 8 de julio de 1999.

CEDH No 28396/95, Wille v. Liechtenstein, de 28 de octubre de 1999.

CEDH N ${ }^{\circ}$ 23118/93, Nilsen and Johnsen v. Noruega, de 25 de noviembre de 1999.

CEDH No 34000/96, Roy et Malaurie v. Francia, de 3 de octubre de 2000.

CEDH No 48898/99, Perna v. Italia, de 25 de julio de 2001.

CEDH No 31611/96, Nikula v. Finlandia, de 21 de marzo de 2002.

CEDH No 53886/00, Tourancheau et July v. Francia, de 24 de noviembre de 2005.

CEDH No 28070/06, A. v. Noruega, de 9 de abril de 2009. 
CIDH, Lori Berenson v. Perú, sentencia de 24 de noviembre de 2004.

Murray v. Brancato, 264 App. Div. 862, decidida el 4 de marzo de 1943.

Nebraska Press Assn. v. Stuart, 427 U.S. 539 (1976).

Sheppard v. Maxwell, 384 U.S. 333 (1966).

STC 30/1982.

STC 23/1985.

STC 109/1986.

STC 107/1988.

STC 171/1990.

STC 65/1992.

STC 219/1992.

STC 178/1993.

STC 320/1994.

STC 128/1995.

STC 166/1995.

STC 173/1995.

STC 28/1996.

STC 3/1997.

STC 139/1997.

STC 46/1998.

STC 136/1999.

STC 154/1999.

STC 162/1999.

STC 187/1999.

STC 151/2000.

STC 64/2001.

STC 69/2001.

STC 155/2002.

STC 54/2004.

STC 56/2004.

STC 57/2004.

STC 1/2005.

STC 244/2007. 
STS de 4 de marzo de 1991.

STS de 3 de diciembre de 1992.

STS de 14 de julio de 1999.

STS de 27 de septiembre de 1999.

STS de 9 de febrero de 2004.

\section{NORMAS JURÍDICAS CITADAS}

Anteproyecto de la Ley de Enjuiciamiento Criminal de 27 de julio de 2011.

Auto Pleno 394/2006 de 7 de noviembre.

Barómetro interno de opinión de la abogacía española 2013, Informe General 31 de enero de 2013.

Carta Europea de Derechos Humanos.

Centro de Investigaciones Sociológicas (CIS) Barómetro número 2861, de febrero de 2011.

CGPJ: Comunicado de 2 de enero de 1995.

CGPJ: Declaración del Pleno, de 25 de enero de 1995.

Circular de 2 de enero de 1899 del Fiscal Jefe del Tribunal Supremo.

Código Deontológico de la Federación de Asociaciones de Prensa de España.

Convención Europea de Derechos Humanos.

Directiva 2005/20 UE.

Directiva 2012/29 UE.

Informe 2013 de la Actividad Judicial elaborado por el Observatorio de la Actividad de la Justicia, Fundación Wolters Kluwer.

Instrucción 3/1993 del Ministerio Fiscal, de 16 de marzo.

Instrucción 3/2005 del Ministerio Fiscal.

Ley de Enjuiciamiento Criminal (LECrim).

Ley Orgánica del Poder Judicial (LOPJ).

LO 19/1994.

Recomendación (2003) 13 del Consejo de Europa.

Revista del Poder Judicial. Número especial XVII: Justicia, información y opinión pública. I Encuentro Jueces-Periodistas. (1999). 